\title{
Inhibition of HMG-CoA reductase and lipid peroxidation in the rats liver by selected zingiberaceae
}

\author{
Patonah Hasimun*, Agus Sulaeman, Hendra Mahakam Putra, Heni Lindasari \\ Bandung School of Pharmacy \\ Jl. Sukarno Hatta, Cibiru, Bandung, West Java, Indonesia
}

Submitted: 29-03-2018

Reviewed: 09-11-2018

Accepted: 06-12-2108

\begin{abstract}
Cardiovascular disease is the leading cause of death worldwide. One of the major risk factors for cardiovascular disease is hyperlipidemia. This study aimed to determine the potential of Zingiberaceae (10 species) as inhibitor of HMG-CoA reductase enzyme activity and lipid peroxidation. This study was conducted by 2 methods including assay of HMG-CoA reductase inhibition and lipid peroxidation test. The study was performed by in vitro method, using $20 \%$ rat liver homogenate. The inhibition of HMG-CoA reductase enzyme was done by reacting liver homogenate, HMG-CoA substrate, which added the Zingiberaceae extract compared with simvastatin as standard drug. The absorbance of the mixture was measured by a Microlab 300 spectrophotometer at a $340 \mathrm{~nm}$ wavelength. Lipid peroxidation assay was induced by the $\mathrm{FeSO}_{4} \cdot 7 \mathrm{H}_{2} \mathrm{O}$ solution. The absorbance value measured using a spectrophotometer at a $532 \mathrm{~nm}$ wavelength. Lipid peroxidation inhibition was characterized by absorbance of the test extract, compared with the control group. The obtained data was calculated as percent of inhibition and was used to calculate $\mathrm{IC}_{50}$ extract test. The results showed that the 10 ethanolic extracts of Zingiberaceae rhizomes have activity as inhibitor HMG-CoA reductase enzyme with $\mathrm{IC}_{50}$ value range $65.8 \pm 4.1-203.3 \pm 15.2 \mathrm{ppm}$ and $\mathrm{IC}_{50}$ for simvastatin as standard drug was $6.8 \pm 0.1 \mathrm{ppm}$. Inhibition of lipid peroxidation with $\mathrm{IC}_{50}$ value range $13.5 \pm 5.0-$ $219.6 \pm 4.3 \mathrm{ppm}$ and simvastatin as standard drug was $1.8 \pm 0.5 \mathrm{ppm}$. This study can be concluded that the Zingiberaceae rhizomes have potential role as antihyperlipidemic agents through inhibition of HMG-CoA reductase enzyme activity and preventing lipid peroxidation.
\end{abstract}

Keywords: hyperlipidemia, HMG-CoA reductase inhibitor, lipid peroxidation, zingiberaceae

\author{
*Corresponding author: \\ Patonah Hasimun \\ Bandung School of Pharmacy \\ J1. Sukarno-Hatta no 754, Cibiru, Bandung, West Java, Indonesia \\ Email: patonah@stfb.ac.id
}




\section{INTRODUCTION}

Cardiovascular disease is the leading cause of death worldwide. The World Health Organization (WHO) reports that hyperlipidemia is a major risk factor for cardiovascular disease and atherosclerosis. About $31 \%$ of deaths caused by cardiovascular disease include coronary heart disease and stroke (Mendis, Puska, Norrving, \& Organization, 2011). The initial stage of coronary heart disease (CHD) is hyperlipidemia. Hyperlipidemia is a metabolic disorder indicated by an increase in total cholesterol, low-density lipoprotein (LDL), or triglycerides, and a decrease in high-density lipoprotein (HDL), or combination of both in the blood (Wells, DiPiro, Schwinghammer, \& DiPiro, 2014). It has been found that there is an inverse relationship between HDL cholesterol levels and coronary heart disease risk (Rader \& Hovingh, 2014). Moreover, the oxidized LDL lipoprotein (oxLDL) or lipid peroxidation in hyperlipidemia plays an important role in atherogenesis by increasing the lipid deposit in the arterial wall (Moriel et al., 2000). The presence of oxLDL is a biomarker of cardiovascular disease (Trpkovic et al., 2015).

There is a relationship between the prevalence of hyperlipidemia and hypertension. Hypertension and hypertriglyceridemia are important components of the metabolic syndrome. Therefore, the increasing prevalence of these components leads to metabolic disease. Moreover, the relationship between blood pressure, central obesity, and the high levels of insulin, not only observed in adults, but has also been detected in children and adolescents. The increased prevalence of hyperlipidemia will be associated with the increasing prevalence of hypertension, result in the increase cardiovascular risk factors. Thus, cardiovascular disease can be prevented by preventing the main risk factor. (Bhalavi, Deshmukh, Atram, \& Mahajan, 2014).

HMG-CoA reductase is an enzyme that plays a role in controlling the biosynthesis of endogenous cholesterol in the liver. HMG-CoA reductase catalyzes HMG-CoA conversion into mevalonate, as a sterol precursor including cholesterol. The pathogenesis of hyperlipidemia may be due to hyperactivity of the HMG-CoA reductase enzyme. This enzyme is a target of statin drugs, namely the class of HMG-CoA reductase inhibitors. Statins work through inhibition of endogenous cholesterol biosynthesis in the liver thus increasing LDL receptor activity in the liver thereby increasing the clearance of LDL cholesterol in plasma. In addition, statins can also decrease LDL production by decreasing the production of very low-density lipoprotein (VLDL) in the liver. Statins as first-line hyperlipidemic drugs not only improve lipid profile but also improve vascular inflammation as the initial process of atherosclerosis (Blum, 2014). Therefore, drug research that can inhibit the enzyme HMG-CoA reductase is very potential to be developed, especially from herbal medicines.

The prevalence of hyperlipidemia is still high and increasing every year, especially in Indonesia, indicating that the existing treatment has not been able to control the disease. It is an opportunity to find a safer and more effective drug in treating hyperlipidemia, using Indonesian herbal medicine. Family Zingiberaceae has been used in Indonesia to overcome various diseases including hyperlipidemia.

The Zingiberaceae family has held an important place for hundreds of years. Because of infusions and tinctures from these plants and other aromatic species have been used and are still used today as a component of herbal medicine to treat a variety of diseases (Tripathi \& Singh, 2015). Zingiberaceae is a widely studied plant family and a potential source of medicinal plants. Various studies have shown that Zingiber officinale var rubrum has the potential to lower cholesterol, lower blood glucose levels and antioxidants (Srinivasan, 2017). Previous research has shown that Zingiberaceae can inhibit the alpha-glucosidase enzyme (Hasimun et al., 2016). This study aimed to determine the potential role of Zingiberaceae family (10 species) on the activity of HMG-CoA reductase enzyme. So the results of this study can optimize the use of Zingiberaceae family as a blood cholesterol-lowering agent. 


\section{MATERIALS AND METHODS \\ Plant materials}

The study conducted using 10 species of Zingiberaceae namely: Zingiber littorale Nor., Zingiber aromaticum Val., Zingiber zerumbet (L) J.E.Smith., Zingiber cassumunar Roxb., Zingiber ottensi Val, Zingiber officinale Var officinarum, Zingiber officinale Var. Amarum., Zingiber officinale Var. Rubrum., Kaempferia galanga L., Alpinia galanga (L) Sw.This research uses rhizome plant parts. Zingiberaceae rhizome obtained from Manoko Lembang, Bandung, West Java. Plants have been carried out botanical identification in the Biology Laboratory, Faculty of Mathematics and Natural Sciences, Padjadjaran University, Bandung, West Java, Indonesia.

\section{Preparation extract}

The dried Zingiberaceae rhizomes were extracted using 96\% ethanol solvent (purchased from Brataco, Bandung, Indonesia) by maceration method for 3 days. The filtrate was filtered, and concentrated using rotary evaporator at $60{ }^{\circ} \mathrm{C}$ and dried over a water bath at $60{ }^{\circ} \mathrm{C}$.

\section{Phytochemical screening}

Phytochemical screening was performed on ethanol extract of 10 Zingiberaceae rhizomes. Phytochemical screening aimed to identify classes of secondary metabolite compounds contained in Zingiberaceae rhizomes such as alkaloids, flavonoids, tannins, saponins, steroids.

\section{Experimental design}

Three Wistar 2-month-old male rats weighing 200-250 grams obtained from D'Wistar (Majalaya, Bandung, West Java, Indonesia). Test animals were acclimatized for 7 days in a cage with standard feed and drinking water, as well as 12 light dark duty cycles maintained. All treatments performed on test animals during the study were approved by the Ethical Committee of the Faculty of Medicine, Padjadjaran University, Bandung, West Java, Indonesia (No: 26/ UN6.C.10/PN/ 2018).

After acclimatization, the rats were sacrificed and the liver organ were isolated to make $20 \%$ liver homogenate in buffer phosphate $\mathrm{pH}$ 7.4.

\section{HMG-CoA reductase enzyme activity assays}

Prior to the test, a preliminary test of optimization of HMG-CoA substrate concentration was required to react with HMG-CoA reductase enzyme in liver homogenate $20 \%$. The preliminary test was conducted to determine the optimum substrate concentration to react with HMG-CoA reductase enzyme. The results of the optimization obtained the substrate concentration required to activate HMG-CoA reductase enzyme in a homogenate of $20 \%$ was $0.1 \mathrm{ppm}$. Then the optimum concentration of HMG-CoA substrate was used to test enzyme activity in $20 \%$ homogenate of rat liver incubated with Zingiberaceae extract.

The test was performed by making the homogenate of the liver isolated from the liver of the test animal. The isolated liver was cleansed by $0.9 \% \mathrm{NaCl}$. The cleansed and weighed liver was then cut into small pieces, and weighed to make $20 \%$ homogenate in phosphate buffer $\mathrm{pH} 7.4$ and centrifuged at $8000 \mathrm{rpm}$, to form supernatant and residue. The supernatant was separated from the residue as a sample (homogenate).

A $50 \mu \mathrm{L}$ homogenate of $20 \%$ liver was added with $260 \mu \mathrm{L}$ phosphate buffer $\mathrm{pH} 7.4,42 \mu \mathrm{L}$ Na2EDTA (purchased from Bratachem) $50 \mathrm{mM}, 60 \mu \mathrm{L}$ Dithiothreitol ((purchased from Sigma) 100 $\mathrm{mM}, 50 \mu \mathrm{L} \mathrm{KCl} \mathrm{2,16} \mathrm{M,} 12 \mu \mathrm{L}$ substrate HMG-CoA (purchased from Sigma). The mixture was vortex for 10 secs and incubated for 30 minutes (at $37^{\circ} \mathrm{C}$ ). then added 55 NADPH (purchased from Sigma) $1,105 \mathrm{mM}$ and vortex for $10 \mathrm{secs}$ and then incubation for $30 \mathrm{~min}\left(\right.$ at $37^{\circ} \mathrm{C}$ ) (Table I). The incubation process is carried out to ensure the reaction between the substrate and the enzyme HMG-CoA reductase as well as the test extract. The reaction will produce color with different intensity, the absorbance of the mixture was measured by a Microlab 300 spectrophotometer at a $340 \mathrm{~nm}$ wavelength. The presence of inhibition of HMG-CoA reductase enzyme activity was characterized by decreasing sample absorbance value. 


\section{Lipid peroxidation assays}

The lipid peroxidation activity test follows Selvam et al. (1987) with slight modifications. Lipid peroxidation was induced by the $\mathrm{FeSO} 4.7 \mathrm{H} 2 \mathrm{O}$ solution. The short test procedure was as follows: 2.2 $\mathrm{mL}$ of phosphate buffer $\mathrm{pH} 7.4,0.2 \mathrm{~mL}$ FeSO4.7H2O $10 \mathrm{mM}$ and $0.6 \mathrm{~mL}$ of liver homogenate were incubated in a mechanical shaker incubator at $37^{\circ} \mathrm{C}$ for $60 \mathrm{~min}$. Added $0.5 \mathrm{~mL}$ of $40 \%$ trichloroacetic acid, $0.25 \mathrm{~mL} \mathrm{HCl} 5 \mathrm{~N}$ and $0.5 \mathrm{~mL} 2 \%$ thiobarbituric acid. The mixture was stirred and then incubated in a water bath at $100{ }^{\circ} \mathrm{C}$ for 10 minutes. The tube was cooled, then added $3 \mathrm{ml}$ of chloroform and stirred. All test tubes were centrifuged at $2500 \mathrm{rpm}$ for 10 minutes. The organic layer was separated (bottom). The supernatant absorbance was measured by spectrophotometer at $532 \mathrm{~nm}$ wavelength (Selvam \& Kurien, 1987).

\section{Data Analysis}

The data obtained were shown as percent of inhibition. Increased percentage inhibition is proportional to the potential of the test extract as an inhibitor. Data was shown as the average value and standard deviation $(n=3)$. The IC50 was obtained by calculation of the percent value of inhibition at 3 different concentrations.

\section{RESULT AND DISCUSSION}

The extract yield of 10 Zingiberaceae rhizomes was obtained by maceration using $96 \%$ ethanol solvent for 3 days presented in Table I. The results of phytochemical screening of dried rhizomes are shown in Table II.

Table I. The yield of rhizome extracts of 10 species from the Zingiberaceae family (macerated by $96 \%$ ethanol)

\begin{tabular}{lc}
\hline Zingiberaceae & Yield (\%) \\
\hline Alpinia galanga $(\mathrm{L})$ Sw. & 1.6 \\
Kaempferia galanga L. & 1.7 \\
Zingiber littorale Nor. & 1.8 \\
Zingiber zerumbet (L) J.E.Smith. & 1.9 \\
Zingiber officinale Var. Amarum & 2.5 \\
Zingiber officinale Var. Officinarum & 0.8 \\
Zingiber officinale Var. Rubrum & 2.2 \\
Zingiber aromaticum Val. & 1.2 \\
Zingiber ottensi Val. & 2.8 \\
Zingiber cassumunar Roxb. & 2.9 \\
\hline
\end{tabular}


Table II. Phytochemistry compounds from 10 species of Zingiberaceae family

\begin{tabular}{|c|c|c|c|c|c|}
\hline \multirow{2}{*}{ Zingiberaceae } & \multicolumn{5}{|c|}{ Content of } \\
\hline & Alkaloid & Flavonoid & Saponin & Steroid & Tanin \\
\hline Alpinia galanga $(\mathrm{L}) \mathrm{Sw}$. & - & - & - & - & + \\
\hline Kaempferia galanga $\mathrm{L}$. & - & - & - & + & + \\
\hline Zingiber aromaticum Val. & - & + & + & - & + \\
\hline Zingiber cassmunar Roxb. & - & + & - & - & + \\
\hline Zingiber littorale Nor. & + & - & + & - & + \\
\hline Zingiber officinale Var. Amarum & - & + & - & + & - \\
\hline $\begin{array}{l}\text { Zingiber } \\
\text { Officinarum }\end{array}$ officinale $\quad$ Var. & + & + & - & - & + \\
\hline Zingiber officinale Var. Rubrum. & + & + & - & - & + \\
\hline Zingiber ottensi Val & - & + & - & + & + \\
\hline Zingiber zerumbet (L) J.E.Smith. & - & + & + & + & - \\
\hline
\end{tabular}

$(+)$ : present , (-): absent

\section{Zingiberaceae rhizomes as inhibitor HMG-CoA Reductase}

The addition of Zingiberaceae extract to rat liver homogenate decreases the activity of HMGCoA reductase enzyme indicated by decreased absorbance value of NADPH. This occurs because of inhibition of HMG-CoA reductase enzyme activity by Zingiberaceae extract where this enzyme activity always requires NADPH as a cofactor. NADPH undergoes an oxidation-reduction reaction that will be converted to $\mathrm{NADP}^{+}$and produces a color reaction when the active HMG-CoA reductase enzyme converts HMG-CoA into mevalonic acid and then converted to cholesterol.

The percent of inhibition obtained from the absorbance value was used to calculate the $\mathrm{IC}_{50}$ value of the Zingiberaceae extract. $\mathrm{IC}_{50}$ value shows the amount of Zingiberaceae extract concentration that can inhibit the activity of HMG-CoA Reductase enzyme by 50 percent. The smaller concentrations of $\mathrm{IC}_{50}$ indicate that the stronger activity of extract as an HMG-CoA reductase enzyme inhibitor (Table III).

Table III. IC $_{50}$ concentration of Zingiberaceae rhizome as HMG-CoA reductase inhibitor

\begin{tabular}{lc}
\hline Zingiberaceae & IC $_{\mathbf{5 0}}(\mathbf{p p m})$ \\
\hline Simvastatin & $6.8 \pm 0.1$ \\
Zingiber officinale Var. Rubrum & $65.8 \pm 4.1$ \\
Zingiber littorale Nor. & $73.0 \pm 8.7$ \\
Zingiber cassumunar Roxb. & $73.6 \pm 8.7$ \\
Zingiber ottensi Val. & $74.1 \pm 6.0$ \\
Zingiber officinale Var. Officinarum & $74.2 \pm 13.6$ \\
Zingiber officinale Var. Amarum & $76.7 \pm 2.8$ \\
Zingiber aromaticum Val. & $88.1 \pm 2.2$ \\
Zingiber zerumbet $(\mathrm{L})$ J.E.Smith. & $89.1 \pm 5.3$ \\
Alpinia galanga $(\mathrm{L})$ Sw. & $199.6 \pm 6.5$ \\
Kaempferia galanga L. & $203.3 \pm 15.2$ \\
\hline ues are expressed as mean and error bar $(\mathrm{n}=3)$. \\
0 obtained from regression line of percentage inhibition.
\end{tabular}


Previous studies have reported that extract of Zingiber officinale Rosc. decreased liver enzyme activity such as AST, ALT, ALP and LDH, which increases due to iron accumulation in the liver (Gholampour, Ghiasabadi, Owji, \& Vatanparast, 2017). Other studies have reported that the ethanol extract leaves Zingiber officinale Rosc has potent antioxidant activity (Tohma et al., 2017). Clinical studies in patients with type 2 diabetes mellitus, supplementation of Zingiber officinale improves glycemic control of patients. Its therapeutic effects occur through various mechanisms including inhibiting lipid peroxidation (Shidfar et al., 2015). Therefore, supplementation of Zingiber officinale may reduce the risk of chronic complications of diabetes (Khandouzi et al., 2015).

This study showed that the most potent inhibition potential of Zingiberaceae extracts against HMG-CoA reductase and lipid peroxidation activity are Zingiber officinale Var. Rubrum. and Zingiber littorale Nor. The effect of red ginger (Zingiber officinale Var. Rubrum) as an inhibitor of HMG-CoA reductase supports the results of previous studies which reported that red ginger has antihyperlipidemic activity capable of reducing total cholesterol and triglyceride levels and increasing HDL levels (Safitri, Kurniati, Adharani, Suciyati, \& Adnyana, 2016). Zingiber littorale is one of 3 types of Zingiber zerumbet variants. The activity of Zingiber littorale as an inhibitor of HMG-CoA reductase enzyme, was first reported in this study. The results of previous studies showed that zerumbone, a sesquiterpene of Zingiber zerumbet Smith, was reported as an active compound that plays an important role in the inhibitory effect of the HMG-CoA reductase enzyme (Tzeng, Lu, Liou, Chang, \& Liu, 2014)

\section{CONCLUSION}

Based on the results of this study can be concluded that Zingiberaceae rhizome ethanol extract has antihyperlipidemic activity through the mechanism of inhibition of liver enzyme HMG-CoA reductase and prevent lipid peroxidation therefore it may have potential activitiy as antihyperlipidemia and anti-atherosclerosis.

\section{ACKNOWLEDGEMENT}

The authors thank to P3M-STFB for the financial support as Internal Research of STFB.

\section{REFERENCES}

Bhalavi, V., Deshmukh, P., Atram, M., Mahajan, B., 2014. Study of hypertension and hyperlipidemia in the adolescent of central India. Int J Recent Trends Sci Technol, 10(3): 495-498.

Blum, A., 2014, HMG-CoA reductase inhibitors (statins), inflammation, and endothelial progenitor cells - new mechanistic insights of atherosclerosis. Biofactors, 40(3): 295-302.

Borchani, M., Samet-Bali, O., Attia, H., Felfoul, I., Ayadi, M. A., 2017. Effect of ginger (Zingiber officinalis) addition on fermented bovine milk: rheological properties, sensory attributes and antioxidant potential. Journal of New Sciences, 44: 2400-2409.

Gholampour, F., Ghiasabadi, F. B., Owji, S. M., Vatanparast, J., 2017. The protective effect of hydroalcoholic extract of Ginger (Zingiber officinale Rosc.) against iron-induced functional and histological damages in rat liver and kidney. Avicenna Journal of Phytomedicine, 7(6): 542.

Hasimun, P., Lisnasari, E., 2016. Potential alpha-glucosidase inhibitor from selected Zingiberaceae family. Asian Journal of Pharmaceutical and Clinical Research, 9:164-167.

Kajal, A., Kishore, L., Kaur, N., Gollen, R., Singh, R., 2016. Therapeutic agents for the management of atherosclerosis from herbal sources. Beni-Suef University Journal of Basic and Applied Sciences, 5(2): 156-169.

Khandouzi, N., Shidfar, F., Rajab, A., Rahideh, T., Hosseini, P., Taheri, M. M., 2015. The effects of ginger on fasting blood sugar, hemoglobin A1c, apolipoprotein B, apolipoprotein AI and malondialdehyde in type 2 diabetic patients. Iranian Journal of Pharmaceutical Research: IJPR, 14(1): 131.

Mendis, S., Puska, P., Norrving, B., 2011. Global atlas on cardiovascular disease prevention and control. Geneva: World Health Organization. 
Moriel, P., Plavnik, F. L., Zanella, M. T., Bertolami, M. C., Abdalla, DSP., 2000. Lipid peroxidation and antioxidants in hyperlipidemia and hypertension. Biological Research, 33(2): 105-112.

Qudoos, A., Nia, K., Hakro, S., \& Murad, S., 2016. Single blind placebo-controlled study on comparision of effects of zingiber officinale before and after treatment in hyperlipidemia. Journal of Drug Delivery and Therapeutics, 6(3): 90-92.

Rader, D. J., Hovingh, G. K., 2014, HDL and cardiovascular disease. The Lancet, 384(9943): 618625.

Rouhi-Boroujeni, H., Rouhi-Boroujeni, H., Heidarian, E., Mohammadizadeh, F., Rafieian-Kopaei, M., 2015, Herbs with anti-lipid effects and their interactions with statins as a chemical antihyperlipidemia group drugs: A systematic review. ARYA Atherosclerosis, 11(4): 244.

Safitri, D., Kurniati, N., Adharani, S., Suciyati, S., \& Adnyana, I., 2016, The study of red ginger rhizomes ethanol extract (Zingiber officinale roscoe var. sunti val.) on hyperlipidemic-induced rats. PhOL, 3: 15-21.

Selvam, R., \& Kurien, T. B., 1987, Induction of lipid peroxidation by oxalate in experimental rat urolithiasis. Journal of Biosciences, 12(4): 367.

Shidfar, F., Rajab, A., Rahideh, T., Khandouzi, N., Hosseini, S., \& Shidfar, S., 2015. The effect of ginger (Zingiber officinale) on glycemic markers in patients with type 2 diabetes. Journal of Complementary and Integrative Medicine, 12(2): 165-170.

Srinivasan, K., 2017, Ginger rhizomes (Zingiber officinale): a spice with multiple health beneficial potentials. PharmaNutrition, 5(1): 18-28.

Tohma, H., Gülçin, İ., Bursal, E., Gören, A. C., Alwasel, S. H., Köksal, E., 2017. Antioxidant activity and phenolic compounds of ginger (Zingiber officinale Rosc.) determined by HPLC-MS/MS. Journal of Food Measurement and Characterization, 11(2): 556-566.

Tripathi, P., Singh, A., 2015. Indigenous Asian Plants against Cancer: A Comprehensive Review. International Journal of Plant Research, 5(4): 80-86.

Trpkovic, A., Resanovic, I., Stanimirovic, J., Radak, D., Mousa, S. A., Cenic-Milosevic, D., Isenovic, E. R., 2015, Oxidized low-density lipoprotein as a biomarker of cardiovascular diseases. Critical Reviews in Clinical Laboratory Sciences, 52(2): 70-85.

Tzeng, T.-F., Lu, H.-J., Liou, S.-S., Chang, C. J., \& Liu, I.-M., 2014. Lipid-lowering effects of zerumbone, a natural cyclic sesquiterpene of Zingiber zerumbet Smith, in high-fat diet-induced hyperlipidemic hamsters. Food and Chemical Toxicology, 69: 132-139.

Wells, B. G., DiPiro, J. T., Schwinghammer, T. L., DiPiro, C. V., 2014. Pharmacotherapy Handbook, 9/E. McGraw Hill Professional.

Würtz, P., Wang, Q., Soininen, P., Kangas, A. J., Fatemifar, G., Tynkkynen, T., Hughes, A. D., 2016. Metabolomic profiling of statin use and genetic inhibition of HMG-CoA reductase. Journal of the American College of Cardiology, 67(10): 1200-1210. 
